Endocrinol. Japon. 1986, 34 (2), 245-250

\title{
Effect of Thyroid Hormone on Peroxisomal Flavin Enzymes in Rat Liver and Kidney
}

\author{
KazUo ICHIKAWAa, KIYoshi HASHIZUMEa*, TAKASHI YAMADAa \\ AND TAKASHI HASHIMOTOb
}

\begin{abstract}
Department of Gerontology, Endocrinology and Metabolism ${ }^{\mathbf{a}}$ and Department of Biochemistryb, Shinshu University School of Medicine, Matsumoto 390 Japan
\end{abstract}

\begin{abstract}
The Effect of thyroid hormone on peroxisomal enzyme activity was studied in thyroidectomized- and $\mathrm{T}_{4}$-administered-thyroidectomized rats. In liver, the activities of isozyme A of L- $\alpha$-hydroxyacid oxidase, D-amino acid oxidase, urate oxidase and catalase were decreased by thyroidectomy, and the diminished enzyme activities were restored by $T_{4}$ administration to rats. These modifications induced by thyroidectomy or by $\mathrm{T}_{4}$ administration, however, were prominent only in immature animals (20-day-old rats). Although the changes in- $\alpha$-hydroxyacid oxidase and D-amino acid oxidase activities, induced by thyroidectomy or by $\mathrm{T}_{4}$ administratration, were also observed in 40-day-old rats, those in urate oxidase and catalase activities were not significant in 40-dayold rats. Acyl CoA oxidase activity was not affected by thyroidectomy or by $\mathrm{T}_{4}$ administration in either 20- or 40-day-old rats. In the kidney, isozyme $\mathrm{B}$ of L- $\alpha$-hydroxiacid oxydase activity was reduced by thyroidectomy and the diminished enzyme activity was restored by $\mathrm{T}_{4}$ administration in both 20 - and 40-day-old rats. D-Amino acid oxidase and catalase activities in kidney, however, were not significantly modified by throidectomy or by $\mathrm{T}_{4}$ administration in either 20- or 40-day-old rats. The results suggest that thyroid hormone can modify the peroxisomal enzyme activity, which is prominent in immature animals.
\end{abstract}

It is well known that flavin nucleotide enzymes are essential components of a number of oxidases, many of which utilize $\mathrm{O}_{2}$. Thyroid hormone is known to regulate the conversion of riboflavin into coenzymes flavin mononucleotide and flavin adenine dinucleotide (Rivlin and Langdon, 1979; Fazekas et al., 1978). They reported that

\footnotetext{
Received August 26, 1986

* To whom requests for reprints may be addressed.
}

thyroid hormone stimulates the synthesis of these coenzymes by increasing the activity of flavokinase. On the other hand, it is uncertain whether the enzymes which require these coenzymes are influenced by thyroid hormone. Peroxisome is one of the organelles which are enriched in flavin coenzyme requiring enzymes (Dixon and webb, 1979). Various enzymes, involved in fatty acid activation and oxidation (Lazarow and DeDuve, 1976; Bronfman et al., 1979) and intracellular transport of fatty acyl moieties 
(Markwell et al., 1972), have been localized in peroxisomes. In this study, we aimed to examine whether thyoroid hormone can modify the activity of several oxidases which are present in peroxisomes.

\section{Materials and Methods}

\section{Animal preparation}

In experiment 1 , immature male Wistar rats, weighing 50-60 g (20-day-old), were divided into two groups. One of them (5 rats) was shamoperated, and the other (17 rats) was thyroidectomized. The sham-operated rats were injected with saline subcutaneously for 7 days. The thyroidectomized-rats were divided into two subgroups. One of them (8 rats) was injected with saline for 7 days. The other $(9$ rats) was daily injected with thyroxine $\left(\mathrm{T}_{4}\right)$ (dissolved in saline containing $10^{-8} \mathrm{M} \mathrm{NaOH}$ ) at a dose of $20 \mu \mathrm{g} /$ animal subcutaneously for the same period. Twelve $h$ after the last injection of $T_{4}$ or saline, the animals were killed and trunk blood was collected into heparinized plastic tubes. The liver and kidney swere removed and kept at $-20^{\circ} \mathrm{C}$ until use. In experiment 2 , male Wistar rats, weighing 100-105 g (40-day-old), were divided into two groups. One of them (5 rats) was injected with $\mathrm{T}_{4}(20 \mu \mathrm{g} /$ animal $)$ for 7 days and the other (4 rats) was injected with saline as described. Twelve $h$ after the last injection, the blood, liver, and kidney specimens were prepared as described.

\section{Enzyme assay}

Livers and kidneys were homogenized with 5 volumes of $50 \mathrm{mM}$ potassium phosphate buffer ( $\mathrm{pH} 7.5)$, and the homogenates were used as an enzyme source. L- $\alpha$-Hydroxyacid oxidase activity was assayed by measuring the rate of $\mathrm{O}_{2}$ consumption with an oxygraph (Bioxygraph, KyusuiKagaku Inst. Tokyo, Japan) as previously described (Yokota et al., 1985). The reaction mixture contained $0.1 \mathrm{M}$ potassium phosphate buffer ( $\mathrm{pH} 8.0$ ), the substrate, and the enzyme in a final volume of $1.2 \mathrm{ml}$. The concentrations of the substrates were $20 \mathrm{mM}$ glycolate for assay of isozyme A and $20 \mathrm{mM}$ DL- $\alpha$-hydroxybutyrate for assay of isozyme B. One $\mu \mathrm{g}$ of bovine liver catalase was added to correct the effect of endogenous catalase activity on $\mathrm{O}_{2}$ consumption.
Acyl-CoA oxidase was measured as previously described (Hashimoto et al., 1981). D-Amino acid oxidase, urate oxidase and catalase were assayed by the method of Leighton et al. (1968). Enzyme assay was carried out at $30^{\circ} \mathrm{C}$. One unit of enzyme activity was defined as the amount that catalyzed the reaction resulting in the consumption of $1 \mu$ mole of substrate per min.

Quantitative precipitation reaction of $L-\alpha-H y d r o-$ xyacid oxidase

Preparation and purification of isozyme A and $\mathbf{B}$ of $\mathrm{L}-\alpha$-hydroxiacid oxidase and of their antibodies were performed as previously described (Yokota et al., 1985). Liver and kidney were homogenized with three volumes of $50 \mathrm{mM}$ potassium phosphate $(\mathrm{pH} 7.5)$, and centrifuged at $15,000 \times g$ for $20 \mathrm{~min}$. The supernatants were used for quantitative precipitin reaction. Various amounts of the extract were added to the fixed amount of antibody. After incubation at $20^{\circ} \mathrm{C}$ for $30 \mathrm{~min}$. in $0.15 \mathrm{M} \mathrm{NaCl}$ containing $50 \mathrm{mM}$ potassium phosphate $(\mathrm{pH}$ 7.5), the reaction mixture was centrifuged. An aliquot of the supernatant was used for enzyme assay. The precipitate was washed once with $0.15 \mathrm{M} \mathrm{NaCl}$ $50 \mathrm{mM}$ potassium phosphate ( $\mathrm{pH} 7.5)$ containing $2 \%(\mathrm{v} / \mathrm{v})$ Triton $\mathrm{X}-100$, and three times with the same buffer without Triton X-100. The washed precipitate was subjected to protein assay.

\section{Other analytical procedures}

3, 5, 3'-Triiodo-L-thyronine $\left(\mathrm{T}_{3}\right)$ and $\mathrm{T}_{4}$ conconcentrations in serum were measured by radio-immunoassays using commercially available kits (Kaken Kagaku, Tokyo, Japan) as previously described (Hiramatsu et al., 1983). The protein concentration was measured by the method of Lowry et al. (1951) using bovine serum albumin as a standard. Statistical significance was assessed by using Student's $t$-test.

\section{Materials}

$\mathrm{T}_{4}$, glycolate, DL- $\alpha$-hydroxybutyrate, catalase and D-alanine were purchased from Sigma Chemical Co., (St. Louis, MO USA).

\section{Results}

As is shown in Table 1, body weight and 
Table 1. Effects of thyroidectomy or $\mathrm{T}_{4}$ administration to thyroidectomized rats on body weight, liver and kidney weights, and on serum $T_{3}$ and $T_{4}$ concentrations.

\begin{tabular}{|c|c|c|c|c|c|}
\hline Treatment of rats & Body weight & Liver weight & Kidney Weight & $\begin{array}{c}\mathrm{T}_{4} \\
(\mu \mathrm{g} / 100 \mathrm{ml})\end{array}$ & $\begin{array}{c}\mathrm{T}_{3} \\
\text { (ng/100 ml) }\end{array}$ \\
\hline \multicolumn{6}{|l|}{ Exp. 1} \\
\hline $\begin{array}{l}\text { Control } \\
\text { (Sham-operated) (5) }\end{array}$ & $88 \pm 13$ & $3.9 \pm 0.6$ & $1.1 \pm 0.3$ & $5-5 \pm 1.3$ & $75 \pm 4$ \\
\hline $\begin{array}{l}\text { Thyroidectomized } \\
+ \text { Saline }\end{array}$ & $60 \pm 9^{a}$ & $1.8 \pm 0.3^{\mathrm{a}}$ & $0.6 \pm 0.1^{\mathrm{a}}$ & $1.2 \pm 0.9^{a}$ & $49 \pm 17^{e}$ \\
\hline $\begin{array}{l}\text { Thyroidectomized } \\
+\mathrm{T}_{4}(20 \mu \mathrm{g} / \text { day })\end{array}$ & $98 \pm 8^{b}$ & $3.1 \pm 0.5^{b}$ & $1.0 \pm 0.1^{b}$ & $16.2 \pm 4.6^{b}$ & $501 \pm 66^{b}$ \\
\hline \multicolumn{6}{|l|}{ Exp. 2} \\
\hline $\begin{array}{l}\text { Control } \\
\quad \text { (Sham-operated) }\end{array}$ & $182 \pm 19$ & $7.8 \pm 1.0$ & $1.4 \pm 0.1$ & $5.4 \pm 0.2$ & $88 \pm 11$ \\
\hline $\begin{array}{l}\text { Thyroidectomized } \\
+ \text { Saline }\end{array}$ & $95 \pm 14^{a}$ & $3.6 \pm 0.8^{\mathrm{a}}$ & $0.7 \pm 0.1^{\mathrm{a}}$ & $0.3 \pm 0.2^{\mathrm{a}}$ & $35 \pm 8^{a}$ \\
\hline $\begin{array}{l}\text { Thyroidectomized } \\
+\mathrm{T}_{4}(20 \mu \mathrm{g} / \text { day }\end{array}$ & $114 \pm 5^{b}$ & $4.4 \pm 0.6^{b}$ & $1.1 \pm 0.1^{\mathrm{b}}$ & $10.5 \pm 3.4^{b}$ & $199 \pm 29 \mathrm{~b}$ \\
\hline
\end{tabular}

The initial body weight of rats was $54 \pm 4 \mathrm{~g}$ in exp. 1 and $102 \pm 3 \mathrm{~g}$ in Exp. 2. Each value indicates the mean \pm S. D. Parenthesis indicates the number of determinations. Explanations: $\mathrm{a}=\mathrm{p}<0.01$ (compared to control) $\mathrm{b}=<0.01$ (compared to thyroidectomized animals).

Table 2. Effects of thyroidetomy or $\mathrm{T}_{4}$ administration to thyroidectomized rats on peroxisomal enzyme activities in liver.

\begin{tabular}{|c|c|c|c|c|c|}
\hline \multirow[t]{2}{*}{$\begin{array}{l}\text { Treatment } \\
\text { of rats }\end{array}$} & $\begin{array}{l}\text { L- } \alpha \text {-hydroxy- } \\
\text { acid oxidase } \\
\text { A }\end{array}$ & $\begin{array}{l}\text { D-amino } \\
\text { adid } \\
\text { oxidadas }\end{array}$ & $\begin{array}{l}\text { Acyl CoA } \\
\text { oxidase }\end{array}$ & $\begin{array}{l}\text { Urate } \\
\text { oxidase }\end{array}$ & \multirow{2}{*}{$\frac{\text { Catalase }}{\left(\begin{array}{c}\times 10^{-3} \text { units } / g \\
\text { liver }\end{array}\right)}$} \\
\hline & \multicolumn{4}{|c|}{ (units/g liver) } & \\
\hline \multicolumn{6}{|l|}{ Exp. 1} \\
\hline $\begin{array}{l}\text { Control } \\
\text { (Sham-operated) (5) }\end{array}$ & $1.2 \pm 0.2$ & $0.28 \pm 0.08$ & $0.44 \pm 0.21$ & $1.1 \pm 0.5$ & $102 \pm 17$ \\
\hline $\begin{array}{l}\text { Thyroidectomized } \\
\quad+\text { Saline }\end{array}$ & $0.3 \pm 0.1^{\mathrm{a}}$ & $0.41 \pm 0.06^{\mathrm{a}}$ & $0.41 \pm 0.14 \mathrm{c}$ & $0.5 \pm 0.2^{\mathrm{a}}$ & $48 \pm 22^{a}$ \\
\hline $\begin{array}{l}\text { Thyroidectomized } \\
+\mathrm{T}_{4}(20 \mu \mathrm{g} / \text { day })\end{array}$ & $0.9 \pm 0.2^{b}$ & $0.43 \pm 0.14^{b}$ & $0.54 \pm 0.23 \mathrm{~d}$ & $1.0 \pm 0.1^{\mathrm{b}}$ & $98 \pm 19 \mathrm{~b}$ \\
\hline \multicolumn{6}{|l|}{ Exp. 2} \\
\hline $\begin{array}{l}\text { Control } \\
\text { (Sham-operated) }\end{array}$ & $1.1 \pm 0.1$ & $0.47 \pm 0.04$ & $0.33 \pm 0.03$ & $1.4 \pm 0.1$ & $72 \pm 4$ \\
\hline $\begin{array}{l}\text { Thyroidectomized } \\
\quad \text { + Saline }\end{array}$ & $0.4 \pm 0.1^{\mathrm{a}}$ & $0.26 \pm 0.07 \mathrm{a}$ & $0.26 \pm 0.05 \mathrm{c}$ & $1.2 \pm 0.3^{c}$ & $52 \pm 9 \mathrm{e}$ \\
\hline $\begin{array}{l}\text { Thyroidectomized } \\
\quad+\mathrm{T}_{4}(20 \mu \mathrm{g} / \text { day })\end{array}$ & $0.8 \pm 0.1^{b}$ & $0.76 \pm 0.15^{b}$ & $0.38+0.07^{f}$ & $1.5 \pm 0.2^{\mathrm{d}}$ & $60 \pm 6^{d}$ \\
\hline
\end{tabular}

Each value indicates the mean \pm S. D.. Parenthesis indicates the number of determinations. Explanations: $\mathrm{a}=<0.01$ (compared to control); $\mathrm{b}=<0.01$ compared to thyroidectomized animals); $\mathrm{c}=>0.5$ (compared to control); $\mathrm{d}=>0.5$ (compared to thyroidectomized rats); $\mathrm{e}=$ $<0.05$ (compared to control); $\mathrm{f}=<0.05$ (compared to thyroidectomized rats). 
liver and kidney weights were significantly The low levels of serum $T_{3}$ and $T_{4}$ in decreased by thyroidectomy. Administration of $\mathrm{T}_{4}$ to the thyroidectomized-animals thyroidectomized-animals and high levels of prevented the reduction of these weights. them in $\mathrm{T}_{4}$-injected-thyroidectomized-rats were observed in experiments 1 and 2 .

Table 3. Effects of thyroidectomy or $\mathrm{T}_{4}$ admistration to thyroidectomized rats on peroxisomal enzyme activities in kidney.

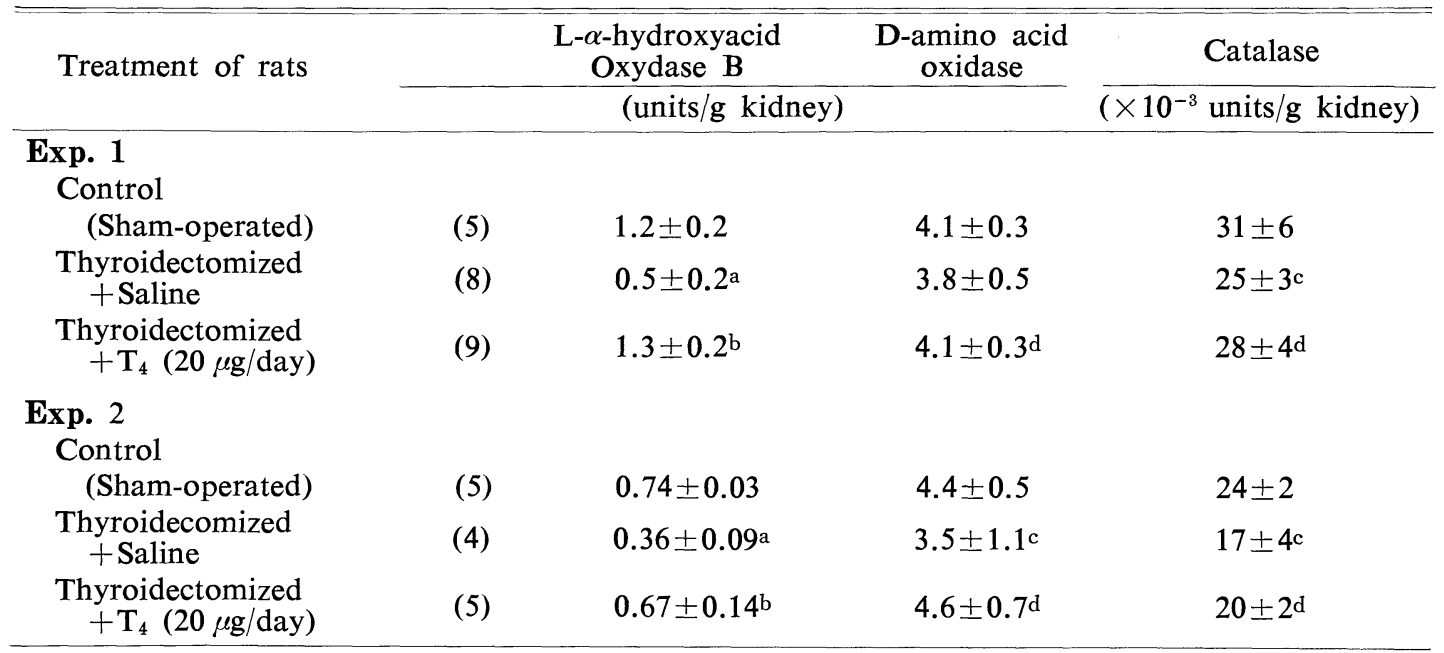

Each value indicates the mean \pm SD. Parenthesis indicates the number of determinations. Explanations : $a=<0.01$ (compared to control); $b=<0.01$ (compared to thyroidectomized rat; $\mathrm{c}=>0.5$ (compared to control); $\mathrm{e}=>0.5$ (compared to thyroidectomized rats).

Table 4. Immunotitration of L- $\alpha$-hydroxyacid oxidase activivity.

\begin{tabular}{|c|c|c|c|c|c|c|}
\hline \multirow{3}{*}{ Source of Enzyme } & \multicolumn{3}{|c|}{ L- $\alpha$-hydroxyacid oxydase A } & \multicolumn{3}{|c|}{ L- $\alpha$-hydroxyaid oxydase B } \\
\hline & $\begin{array}{l}\text { Activity } \\
\text { added }\end{array}$ & $\begin{array}{l}\text { Activity in } \\
\text { supernatant }\end{array}$ & $\begin{array}{l}\text { Protein } \\
\text { precipi- } \\
\text { tated }\end{array}$ & $\begin{array}{l}\text { Activity } \\
\text { added }\end{array}$ & $\begin{array}{l}\text { Activity in } \\
\text { supernatant }\end{array}$ & $\begin{array}{c}\text { Protein } \\
\text { precipi- } \\
\text { tated }\end{array}$ \\
\hline & \multicolumn{2}{|c|}{ (munits) } & $\overline{\left(A_{280 \mathrm{~nm}}\right)}$ & \multicolumn{2}{|c|}{ (munits) } & $\left(\mathrm{A}_{280 \mathrm{~nm}}\right)$ \\
\hline Control rats & 10 & 0 & 0.052 & 10 & 0 & 0.081 \\
\hline (Enzymes were prepared & 40 & 10 & 0.088 & 20 & 0 & 0.103 \\
\hline from rats in Exp. 1) & 85 & 41 & 0.060 & 47 & 31 & 0.088 \\
\hline Thyroidectomized + Saline & 10 & 0 & 0.054 & 10 & 0 & 0.082 \\
\hline (Enzymes were prepared & 40 & 12 & 0.092 & 20 & 0 & 0.097 \\
\hline from rats in Exp. 2) & 85 & 43 & 0.063 & 47 & 29 & 0.062 \\
\hline Thyroidectomized $+\mathrm{T}_{4}$ & 10 & 0 & 0.052 & 10 & 0 & 0.087 \\
\hline (Enzymes were prepared & 40 & 10 & 0.092 & 20 & 0 & 0.098 \\
\hline from rats in Exp. 1) & 85 & 41 & 0.067 & 47 & 31 & 0.073 \\
\hline
\end{tabular}

Isozyme $\mathrm{A}$ and $\mathrm{B}$ were prepared from liver and kidney respectively. The antibodies to isozyme $\mathrm{A}$ and $\mathrm{B}$ were $0.63 \mathrm{mg}$ and $0.73 \mathrm{mg}$ respectively. Procedures for immunotitration are described in Materials and Methods. 
Table 2 summarizes the levels of peroxisomal enzyme activity in liver. In experiments 1 and 2 , the activity of $\mathrm{L}-\alpha-$ hydroxyacid oxidase (isozyme A) was decreased by thyroidectomy. The activity of D-amino acid oxidase was also decreased by thyroidectomy. The diminished activity in these enzymes was restored by $\mathrm{T}_{4}$ administration to the thyroidectomized-rats. The activity of $\mathrm{D}$-amino acid oxidase was dramatically increased by $T_{4}$ administration in comparison with the increase in L- $\alpha$ hydroxyacid oxidase activity. Urate oxidase and catalase activities were also decreased by thyroidectomy and the diminished activities were restored by $\mathrm{T}_{4}$ administration in experiment 1 . The $\mathrm{T}_{4}$-induced increase in urate oxidase or catalase activity, however, was not significant in experiment 2 . In contrast to these enzymes, acyl CoA oxidase activity was not strongly influenced by thyroidectomy or by $\mathrm{T}_{4}$ administration to the animals in both 20 - and 40-day-old rats.

Table 3 summarizes the peroxisomal enzyme activities in kidney. The activity of L- $\alpha$-hydroxyacid oxidase (isozyme B) was decreased by thyroidectomy. The diminished enzyme activity was restored by $\mathrm{T}_{4}$ administration to the thyroidectomized-animals. D-Amino acid oxidase and catalase activities, on the other hand, were not significantly affected by thyroidectomy or by $\mathrm{T}_{4}$ administration to the animals though these activities were decreased by thyroidectomy and increased by $\mathrm{T}_{4}$ administration in experiments 1 and 2 .

Two isozymes of $\mathrm{L}$ - $\alpha$-hydroxyacid oxidase were titrated by the corresponding antibodies. Table 4 shows that the enzyme activities in each liver and kidney tissue of any group were equally inactivated by the corresponding antibody. The equivalence points of the tissue extracts were the same as those of the purified enzyme preparations (Yokota et al., 1985). The immunoprecipitates were analyzed by electrophoresis on a polyacrylamide gel in the presence of sodium dodecylsulfate. The size and the intensity of staining of the subunits of the enzymes were the same in all groups of animals.

\section{Discussion}

In this preliminary report, we have demonstrated that thyroid hormone can modify the several peroxisomal enzyme activities in the liver and kidney. In immature (20-day-old) rats, L- $\alpha$-hydroxyacid oxidase, D-amino acid oxidase, urate oxidase and catalase activities were significantly decresed by thyrodectomy and increased by thyroid hormone administration, whereas the activity of acyl CoA oxidase was not significantly affected by these treatments in the liver, suggesting that the effect of the hormone is enzyme-speeific in peroxisome. The modification induced by thyroid hormone, however, appears to be related to the age of the animals. The thyroid hermone-induced increases in L- $\alpha$-hydroxyacid oxidase and Damino acid oxidase activities in 40-day-old rats were similar to those observed in 20day-old rats, whereas the urate oxidase and catalase responses to thyroid hormone administration were less in 40-day-old rats than those observed in 20-day-old rats. As previously reported, the degree of thyroid hormone action in mitochondria is less in aged animals (Ichikawa et al., (1982). The age-related changes in the response of hepatic enzymes to $\mathrm{T}_{3}$ administration is also reported (Schwartz et al., 1979). Thus, it is possible that thyroid hormone-induced modification of peroxisomal enzyme activities is diminished in aged animals.

As shown in this study, although $\mathrm{L}-\alpha$ hydroxyacid oxidase activity was increased by thyroid hormone in both the liver and kidney, D-amino acid oxidase activity which was significantly increased by the hormone in the liver was not strongly affected by thyroidectomy or by $\mathrm{T}_{4}$ administration in the kidney. The Tissue-specific modification 
induced by thyroid hormone was also observed in the mitochonprial protein synthesis system as previously reported (Ichikawa et al., 1985). Based on these observations, it appears that the thyroid hormone action on peroxisome is also tissue (at least liver and kidney)-specific.

Although we did not measure the concentrations of enzymes, several reports (Rivilin and Langdon, 1979; Fazekas et al., 1978) suggested that the amount of flavin coenzymes is increased by thyroid hormone, suggesting that one of the possible mechanisms by which thyroid hormone increase the activities of peroxisomal enzymes is related to the changes in the concentration of cofactors which are required to stabilize newly synthesized apoenzymes. Immunoprecipitation studies, however, showed that the thyroid hormone increases the net amount of enzymes. The results suggested that not only coenzymes but also several flavin enzymes are newly synthesized by thyroid hormone stimulation. However, further studies, such as quantitative analysis of changes in enzyme activity or in net amount of enzymes, will be required to solve the precise mechanism of stimulation of synthesis of the enzymes.

\section{References}

Bonfman, M., N. C. Inestrosa and F. Leighton (1957). Fatty acid oxidation by human liver microsomes., Biochem. Biophys. Res. Commun., 88, 1030-1036.

Dixon, M. and E. C. Webb (1979). Enzyme biology. in Enzymes (Dixon, M. and E. C. Webb eds.), Longman, London, 622-648.

Fazekas, A. G., J. Pinto, Y. P. Haung, R. Chaudhuri and R. S. Rivlin (1978). Age dependence of thyroxine stimulation of riboflavin incorporation into flavin coenzymes in liver and brain. Endocrinology 102, 641-648.

Hashimoto, T., S. Miyazawa, D. Gunarso and S. Furuta (1981). -amanitin inhibits the oxidation of long chain fatty acids in mouse liver. J. Biochem. 90, 415-421.
Hiramatsu, K., K. Hashizume, T. Aizawa, K. Ichikawa and T. Yamada (1983). Thyrotropin secretion in patients with hyperparathyrodism or hypoparathyroidism : Effect of serum calcium on thyrotropin release. J. Clin. Endocrinol. Metab. 56, 623-626.

Ichikawa, K., K. Hashizume and T. Yamada (1982). Monoamine oxidase inhibitory modulators in rat heart cytosol: Evidene for induction by thyroid hormone. Endocrinology 111, 1803-1809.

Ichikawa, K., K. Hashizume, M. Kobayashi and T. Yamada (1985). Evidence for induction by thyroid hormone of cytosolic proteins which control mitochondrial protein synthesis. Endocrinology 117, 1749-1758.

Lazarow, P. B. and C. DeDuve (1976). A fatty acyl-CoA oxidizing system in rat liver peroxisomes; enhancement by clofibrate, a hypolipidemic drug. Proc. Natl. Acad. Sci. U.S. A. 73, 2043-2046.

Leighton, F., B. Poole, H. Beaufay, P. Baudhuin, J. W. Caffy, S. Fowler and C. DeDuve (1968). The large-scale separation of peroxisomes, mitochondria, and lysosomes from the livers of rats injected with Triton WR-1339. Imported isolated procedures, automated analysis and morphological properties of fractions. $J$. Cell. Biol. 37, 482-513.

Lowry, O. H., N. J. Rosebrough, A. L. Farr and R. J. Randall (1951). Protein measurement with the Folin phenol reagent. J. Biol. Chem. 193, 265-275.

Markwell, M. A. K., E. J. McGroatry, L. L. Bierber and N. E. Tolbert (1972). The subcellular distribution of carnitine acyltransferase in mammalian liver and kidney. A new peroxismal enzyme. J. Biol. Chem. 248, 3426-3432.

Rivlin, R. S. and R. G. Langdon (1969). Effects of thyroxine upon biosynthesis of flavin mononucleotide and flavin adenine dinucleotide. Endocrinology 84, 584-588.

Schwartz, H. L., M. A. Forciea, C. N. Mariash and J. H. Oppenheimer (1979). Age-related reduction of hepatic enzymes to 3, 5, 3'triiodothyronine administration. Endocrinology 105, 41-46.

Yokota, S., K. Ichikawa and T. Hashimoto (1985). Light and electron micrscopic localization of L- $\alpha$-hydroxy acid oxidase in rat kidney revealed by immunocytochemical technique. Histochemistry 82, 25-32. 